Scientific Journal of Agricultural Sciences 2 (1): 31-41, 2020

Print (ISSN 2535-1796) / Online (ISSN 2535-180X)

\title{
Application of Some Fungicides Alternatives for Management Root Rot and Wilt Fungal Diseases of Marigold (Calendula officinalis L.).
}

\author{
Gomma A. Abdel-Wahed \\ Ornamental, Medicinal \& Aromatic Plants Dis. Res. Dept., Plant Pathol. Res. Inst.,ARC, Giza, Egypt. \\ Corresponding author: E mail : gomaaarafat847@yahoo.com
}

Received on: 19/5/2020

Accepted on: 25/6/2020

\begin{abstract}
Root rot and wilt diseases are widespread in Egypt causing severe yield losses on marigold (Calendula officinalis L.) plants. These diseases were detected in Beni-sweif governorate during surveying trials in $2017 / 2018$ and 2018/2019 seasons. The isolated fungi were Fusarium subglutinans, F. oxysporum, F. solani, F.semitectum, F.nivale, F.roseum, Rhizoctonia solani, F. nivale and Pythium splendens which achieved the highest occurrence percentage in isolation trials from samples of Beni- sweif governorate. Fusarium oxysporum was more virulent than the other fungi in pathogenicity tests on marigold. The effect of garlic and onion watery extracts , microelements,macroelements, Ascopine, Potasien, yeast ( Saccharomyces cerevisiae) and fungicides on marigold root rot and wilt diseases incidence were tested under in vitro and in vivo. These controlling agents, however, were varied in their positive efficiency against diseases. Fungicides were the superior treatments in controlling diseases and improving plant growth parameters. In the applied field experiments, all treatments tested significantly decreased the percentages of infection and increased the growth parameters compared with control treatment.
\end{abstract}

KEYWORDS:Marigold (Calendula officinalis L.) , garlic, onion, microelements,macroelements, ascopine, potasien, yeast ( Saccharomyces cerevisiae), fungicides.

\section{INTRODUCTION}

Marigold (C. officinalis L.) has its vernacular name as "pot marigold" and it is an herbaceous plant belonging to the family Asteraceae (Compositae). This family is detailed to have its origin from Mediterranean and West Asia, whereas marigold was moreover begun from Southern Europe and East the Mediterranean (Omed, 2005 ).

Marigold (C. officinalis L.) was utilized to create as a major fancy blooming crop until its proactive as well as medicinally basic compounds were recognized. Oil extracted from this plant besides has its pharmaceutical centrality ( Dinda and Craker, 1998), ( Bernath, 2000 ). Antiviral and antimicrobial potential of marigold has been detected(Mardani-Nejad, et al., 2003).

Marigold is also additionally influenced by a number of fungal pathogens. A few of the important fungal diseases of marigold are bloom blight (Alternaria zinniae), wilt and stem decay (Phytophthora cryptogea), Collar decay (Phytophthora sp.; Pythium sp.), damping- off (Pythium sp.), Alternaria leaf spot, Fusarium wilt (Fusarium oxysporium) and Cercospora leaf spot (Cercospora megalopotamica) (Sohi, 1983).

The causal pathogen of the root rot disease is $R$. solani and the disease is more common at the seedling stage. Necrotic spots and rings create on the youthful seedlings and cause pre-emergence mortality in seedlings whereas appearance of water drenched, brown, necrotic ring on the lower poration of hypocotyl are the post-emergence side effects which cause seedling collapse (Singh et al., 2012). The mycelial growth of $M$. phaseolina, the causal pathogen of jute damping - off, was essentially repressed inhibited in vitro as influenced by garlic bulb extract and the contamination of jute seedlings by the same pathogen was diminished by treating jute seeds by garlic glue (Ahmed and Sultan, 1984). Mycelial growth of $F$. solani, $F$. oxysporum and $F$. acuminatam, the causal of root and basal rots of onion and garlic, was significantly inhibited in vitro as affected by garlic and onion extracts. Also, it was found that garlic extract was more effective than onion against the tested fungi ( Assadi and Behroozin, 1987)

The mycelial growth and sclerotial germination of $R$. solani (Thanatephorus cucumeris), the causal of Phaseolus aures collar rot were significantly inhibited in vitro as affected by garlic water extracts( Lakshmanan and Mohan, 1989). They also reported that the root rot of bean seedlings caused by the previous pathogen was significantly reduced by garlic extract. Microconidia germination and hyphal growth of F.oxysporum f.sp. lycopersici, the causal of tomato wilt, were inhibited by garlic bulb extract ( Tariq and Magee, 2003) Mycelial growth of M.phaseolina, the causal of soybean charcoal root rot was inhibited by extracts of leaves and bulbs of 


\section{Scientific Journal of Agricultural Sciences 2 (1): 31-41, 2020}

fresh onion and garlic ( Dubey and Dwivedi, 1991). Spore germination and mycelial growth of $F$. oxysporum f.sp. melonis, the causal of muskmelon wilt were significantly inhibited by garlic, onion and leek extracts ( Shalaby, (1993)

Control of Botrytis cinerea on geranium rooted cuttings was assed in medicines with phylloplane yeasts (Saccharomyces cerevisiae) in combination with 10 fungicides recommended on Botrytis blight of ornamental plants Buck (2004). A test was carried out during the two progressive seasons (2004/2005 and 2005/2006), to explore the impact of dry yeast and Ascobin foliar fertilizers on development characters and chemical constituents of Ruta graveolens plants (El-Sherbeny et al., 2007). Root rot caused by $R$. solani was enhanced by expanding the level of Nitrogen and diminished by Phosphorus. The effect of Nitrogen was veiled by that of Phosphorus. when they included together (Taya et al., 1988). The aim of this paper evaluation efficacy of some fungicides alternatives in management the root rot and wilt fungal diseases of marigold in vitro and in vivo.

\section{MATERIALS AND METHODS \\ 2.1. Sampling and isolation from infected seedlings and roots:}

Infected parts were cut into pieces which washed totally with running water to expel any taking of soil particles. These pieces were surface sterilized by soaking in 5\% sodium hypocloride for 2 minutes, then washed three times in sterilized water, and dried between sterilized channel papers. Four surface sterilized pieces were aseptically transferred on potato dextrose agar medium (PDA). Plates were incubated at $27 \mathrm{C}^{\circ}$ for $3-7$ days and perceptions were recorded (Christensen, 1957). Hyphal-tip of grown fungi were recultured individually to new PDA plates (Riker and Riker, 1936) and then identified according to their morphological and microscopical characters as described by (Gilman, 1957 and Jens et al., 1991).

The creating colonies were minutely inspected, checked, and the recurrence of each fungus was calculated. Refinement of the confined organism was carried out using the single spore or hyphal tip technique of (Dhingra and Sinclair, 1995). These fungi were identified according to Lestie and Summerell (2006 ), Domsch et al. (1980), Plaats Niterink (1981). The identification, was compassionate affirmed by Mycology and Plant Diseases Survey Dept.,Plant Pathol.Res. Instit. AGRIC.Res. Center, Giza, Egypt. Pure cultures grown onto PDA slants were kept at a low temperature $\left(5 \mathrm{C}^{0}\right)$. The frequency of isolated. fungi was calculated according to the following formula.
Frequency $\%$ of fungus $=$

No of each isolated fungus colonies $\times 100$

Total Number of all isolates

\subsection{Pathogenicity studies:}

Pathogenicty tests were conducted beneath nursery conditions utilizing marigold seeds and seedlings at Agric. Exp. Sta. Sides, Beni-Swief Governorate.

Inocula of the tested fungi, $F$. subglutinans, $F$. oxysporum, $F$. solani, F.semitectum, F.nivale, F.roseum, $R$. solani, $F$. nivale and $P$. splendens were arranged by growing each fungus alone for 15 days at $25 \mathrm{C}^{\circ}$ on maize-meal-sand medium. Formalin-sterilized pots (20-cm-diam) packed with Formalin-sterilized clay and soil $(1: 1, \mathrm{w} / \mathrm{w})$ were separately infested with each fungus at the rate of 1 $\%$ (w/w). Each pot was planted with 25 seeds. Four replicates were used per each particular treatment

Percentages of pre-and post-emergence damping-off and healthy survived seedlings at 30 , 60 and 90 days after sowing were reported, respectively. Growth parameters of seedling / plant (height, fresh and dry weights) were recorded 60 days after sowing.

\subsection{Disease control:}

\subsubsection{Laboratory experiments:}

The effect of any tested material (Table, 1) was inspected against the fungal linear growth of the marigold pathogenic fungi using the poisoned food technique. Each of F.oxysporum, F. solani and $R$. solani, was cultured on five PDA plates per each treatment containing any of the control treatments at the tested concentration. Plates were incubated at 25 $\mathrm{C}^{0}$. Linear growth of fungi was daily examined till growth at one of the treatments covered its plate, and then the mycelial growth was measured.

All the aforementioned treatments (Table 1) were used as root dipping treatments for $15 \mathrm{~min}$. just before transplanting. The marigold seeds were treated with the aforementioned treatments at the same rates.

\subsubsection{Effect of the tested materials on fungal growth:}

According to the percentage of the active ingredient of each fungicide, various weights of the commercial formula were suspended in sterile distilled water, then added to melted PDA just before solidification $\left(45 \mathrm{C}^{0}\right)$ to obtain concentrations of 5, 50,100 and $200 \mathrm{ppm}$.

Concentrations of $0.3,0.4$ and $0.5 \%$ from microelements, macroelements, Ascopine, Potacien and concentrations of $0.1,0.2$ and $0.3 \%$ from yeast solution were prepared applying the previous procedures. The linear growth of the tested fungi were recorded when complete growth of the control treatments done for each fungus. 
Gomma A. Abdel-Wahed., 2020

Table 1. Materials used commercial names, composition and concentrations of the tested through lab. experiments.

\begin{tabular}{|c|c|c|}
\hline Commercial names & Composition & Concentration used \\
\hline Fungicides : & ------ & \\
\hline Topsin M 70\% WP & $\begin{array}{l}70 \% \text { thiophanate - methyl (1,2-bis(3-methoxy } \\
\text { carbonyl-2 thiouredio)benzene) }\end{array}$ & $0.0,5,50,100,200 \mathrm{ppm}$ \\
\hline Vitavax 200 & $37.5 \%$ carboxin $(5,6$ - dihydro- 2 methyl $-1,4-$ & $0.0,5,50,100,200 \mathrm{ppm}$ \\
\hline $75 \% \mathrm{WP}$ & $\begin{array}{l}\text { oxathin }-3-\text { carboxanilide })+37.5 \% \text { Thiram } \\
\text { (tetramethyl thiuram disulfide ) }\end{array}$ & \\
\hline Other compounds & & \\
\hline Ascopine & Organic acids (ascorbic acid and citric acid) & $0.0,0.3,0.4,0.5 \%$ \\
\hline Potasien & Potassium $(30 \%)$ and Nitrogen $(8 \%)$ & $0.0,0.3,0.4,0.5 \%$ \\
\hline Micrelements & Citrin; Fe (2\%), $\mathrm{Zn}(2 \%)$ and $\mathrm{Mn}(2 \%)$. & $0.0,0.3,0.4,0.5 \%$ \\
\hline Macroelements & NPK 202020 & $0.0,0.3,0.4,0.5 \%$ \\
\hline Yeast & Saccharomyces cerevisiae cells & $0.0,1,2,3 \mathrm{gm} / 1$ \\
\hline Garlic & Watery extract of cloves & $0.0,25,50 \%$ \\
\hline Onion & Watery extract of bulbs & $0.0,25,50 \%$ \\
\hline
\end{tabular}

2.3.3. Effect of garlic and onion watery extracts on mycelial growth of the tested fungi:

transplanted with 112 seedlings, 16 ones per each

This experiment aimed to study the effect of garlic and onion extracts on the mycelial growth of the tested fungi. Materials were crushing in blender, then squeezed twice through eight layers of cheese cloth. The extract was filtered through a double cheesecloth fabric and Whatman No.1 filter paper and centrifuged for 10 minutes at $300 \mathrm{rpm}$ to get a clear plant extract. Sterilization was made using 0.45 $\mu \mathrm{m}$ Millipore filter disc. The crude extract was reduced with sterile distilled water to give a series of concentrations of its original volume treatment. (Shalaby, 1993). Two concentrations; i.e.25 and $50 \%$ of garlic and onion extracts were prepared and poured in, melted PDA flask $250 \mathrm{ml}$ just before solidification $\left(40 \mathrm{C}^{0}\right)$ and the poisoned melted media were poured in sterilized Petri dishes plates $9 \mathrm{~cm}$ which were inoculated with equal disks $(4 \mathrm{~mm}$ in diameter) of the desired fungus, taken from 7 dayold cultures. Four replicates were used for each treatment. The control was carried out without addition of any plant extract. The plates were incubated at $25 \pm 2 \mathrm{C}^{0}$. The diameter of the mycelial growth in all treatments was recorded, when the mycelial growth covered the plate surface of the control of each fungus.

\subsection{Field experiments:}

Field experiments were carried out at Agric. Exp. Sta. Sides, Beni-Sweif governorate during two successive seasons, 2017/2018 and 2018/2019 using the complete randomized block design trial .Marigold seedlings 45-days-old (25 cm/long), obtained from the Medicinal \&Aromatic Plants Res. Sta., Hort. Res.Instit., Agric. Res. Center, BeniSwief governorate, were transplanted in the chosen field which was cultivated with marigold several times before. Four replicate plots per each treatment were transplanted with seedlings in October. Each plot (4X5 m; 20m2) with 7 rows was row and $30 \mathrm{~cm}$ as a distance between them. Seedling treatment was carried out using the method of dipping treatment as mentioned before.

The seedlings were directly transplanted after irrigation in the presence of irrigation water. The plants were irrigated every two weeks and all other agricultural practices were performed as usual whenever necessary.

Percentages of infected plants showing root rot and /or wilt diseases symptoms were recorded, five months after planting. Also, fresh weight per plants (g) as well as dry weight were measured at harvest time.

\subsection{Statistical analyses:}

Data obtained were subjected to the statistical analysis according to the standard methods recommended by Gomez and Gomez (1984) using the computer program (costate). Means were compared using L.S.D. at the level 5\% of probability.

\section{Results}

\subsection{Isolation, purification and identification of the isolated fungi organisms and their frequencies:}

Isolation trials were carried out from naturally infected marigold plants showing root rot and /or wilt symptoms collected from different localities in Beni-Swief Governorate. During the experimental course of isolation, fungi were isolated and identified according to their morphological characters, Table (2). F.oxysporum (16.9\%) and $F$. solani $(15.3 \%)$ were the most frequently isolated fungi, Whereas, P. splendens $(7.7 \%)$ and $F$. nivale $(9.2 \%)$ were isolated at low frequencies . 
Table 2. Frequency percentages of the isolated fungi from the wilted and rotted roots of marigold plants collected from BeniSweif governorate.

\begin{tabular}{lll}
\hline Fungi & $\begin{array}{l}\text { No.of } \\
\text { isolates }\end{array}$ & $\begin{array}{l}\text { Frequency } \\
(\%)\end{array}$ \\
\hline Fusarium subglutinams & 34 & 10.4 \\
F.oxysporium & 55 & 16.9 \\
F.semitectum & 40 & 12.3 \\
F.solani & 50 & 15.3 \\
F. nivale & 30 & 9.2 \\
F.roseum & 39 & 12.0 \\
Rhizoctonia solani & 53 & 16.3 \\
Pythium splendens & 25 & 7.7 \\
Total & 326 & 100.00 \\
\hline
\end{tabular}

3.2. Pathogenicity tests:

Data in Table (3) show that all tested fungi were pathogenic to marigold seedlings as they significantly increased percentages of pre-and post emergence damping - off compared with the control treatment. However, the highest percentages of pre and post-emergence damping off were recorded infection with F.oxysporum and R.solani. In contrast, Pythium sp. caused the lowest percentages of pre and post emergence damping- off and high rate of surviving plants, being $8.0,12.0$, and $80 \%$, respectively.

Table 3. Percentages of pre-and post-emergence damping- off and survivals of marigold seedlings after 30,60 and 90 days, of sowing, in infested soil under greenhouse conditions.

\begin{tabular}{|c|c|c|c|}
\hline Fungi & Pre-emergence $(\%)$ & Post-emergence (\%) & $\begin{array}{l}\text { Survivals plant } \\
(\%)\end{array}$ \\
\hline F.oxysporum & 10.0 & 53.0 & 37.0 \\
\hline F.subglutinans & 14.0 & 30.00 & 56.0 \\
\hline Pythium $\mathrm{sp}$ & 8.00 & 12.00 & 80.0 \\
\hline Rhizoctonia solani & 25.00 & 50.00 & 25.0 \\
\hline F.solani & 20.00 & 42.00 & 38.0 \\
\hline$F$, semitectum & 13.0 & 33.0 & 54.0 \\
\hline F.nivale & 12.0 & 35.0 & 53.0 \\
\hline$F$, roseum & 15.0 & 29.0 & 56.0 \\
\hline Control (uninfested soil) & 0.0 & 0.0 & 100.0 \\
\hline L.S.D.at $5 \%$ : & 4.0 & 8.0 & 11.0 \\
\hline $\begin{array}{l}\text { Regarding to the effect } \\
\text { growth parameters of ma } \\
\text { transplanting), data pre } \\
\text { that all tested fungi } \\
\text { marigold plant height ( } \\
\text { (g) compared with those } \\
\text { lowest growth parameter } \\
\text { by infection by F.oxysp } \\
\text { Table 4. Effect of the te } \\
\text { marigold pla } \\
\text { conditions. }\end{array}$ & $\begin{aligned} & \text { fungi on the } 16.4 \\
& \text { (60 days after } \text { dry } \\
& \text { ole (4) reveal } R . s o l \\
& \text { minimized } \text { The } \\
& \text { d dry weights heigh } \\
& \text { eatment. The dry } \\
& \text { were induced F.ros } \\
& 8.5,50.6 \text { and respe } \\
& \text { nic fungi on the gro } \\
& \text { after transplant }\end{aligned}$ & $\begin{array}{l}\text { for plant height, plant } \\
\text { ght, respectively. Me } \\
i \text { occupied the seconc } \\
\text { responding values we } \\
60.3 \mathrm{~g} \text { for plant fresh } \\
\text { ight. In contrast, } \\
m \text { showed the lowe } \\
\text { th parameters and p } \\
\text { in infested soil }\end{array}$ & $\begin{array}{l}\text { sh weight and plant } \\
\text { hile, infection by } \\
\text { nk in this respect. } \\
20.0 \mathrm{~cm} \text { for plant } \\
\text { ight and } 18.5 \mathrm{~g} \text { for } \\
\text { seedlings by } \\
\text { ercentage in this } \\
\text { try weight (g) of } \\
\text { inder greenhouse }\end{array}$ \\
\hline Fungi & $\begin{array}{l}\text { Plant } \\
\text { hight }(\mathrm{cm})\end{array}$ & ight/ plant & ght/plant \\
\hline F.oxysporum & 18.5 & & \\
\hline F.subglutinans & 25.0 & & \\
\hline Pythium sp & 44.2 & & \\
\hline Rhizoctonia solani & 20.0 & & \\
\hline F.solani & 22.9 & & \\
\hline$F$,semitectum & 30.0 & 0.0 & \\
\hline F.nivale & 33.0 & & \\
\hline$F$, roseum & 35.0 & 0.0 & \\
\hline Control (uninfested soil) & 60.0 & 0.0 & \\
\hline L.S.D.at $5 \%$ : & 8.0 & & \\
\hline
\end{tabular}


Gomma A. Abdel-Wahed., 2020

\subsection{Laboratory experiments:}

3.3.1. Effect of fungicides on fungal growth:

Data displayed in Table (5) appear that both tested fungicides significantly inhibited the mycelial growth of the three tested pathogenic fungi to marigold at different degrees as compared with the control treatment. The inhibitory activity of the fungicides significantly increased with the increasing in their concentrations. Topsin $\mathrm{M}$ was significantly the most active fungicide against mycelial growth of F.oxysporum, since it completely inhibited the mycelial growth fungi $(100 \%)$, at 200 ppm concentration. Whereas, Vitavax / Thiram $(0.30 \mathrm{~cm}),(1.0 \mathrm{~cm})$ inhibited mycelia growth for $R$.solani and $F$. solani if compared with Topsin M$70 \quad(0.25 \mathrm{~cm})$ and $(1.0 \mathrm{~cm})$, respectively.

Table 5. Effect of two fungicides on the linear growth $(\mathrm{cm})$ of three pathogenic fungi of marigold plants.

\begin{tabular}{lllllllll}
$\begin{array}{l}\text { loncentrations } \\
\text { (p.p.m) }\end{array}$ & Vitavax / Thiram & \multicolumn{7}{c}{ Topsin M } \\
\hline & F.oxysporum & R.solani & F.solani & Mean & F.oxysporum & R.solani & F.solani & Mean \\
\hline 0.0 & 9.00 & 9.00 & 9.00 & 9.00 & 9.00 & 9.00 & 9.00 & 9.00 \\
5.0 & 5.00 & 3.0 & 3.50 & 3.8 & 2.0 & 2.25 & 3.50 & 2.6 \\
50 & 3.0 & 2.0 & 2.50 & 2.50 & 1.50 & 1.50 & 3.00 & 2.0 \\
100 & 2.0 & 1.0 & 2.25 & 1.75 & 1.00 & 1.25 & 1.25 & 1.2 \\
200 & 0.50 & 0.30 & 1.0 & 1.50 & 0.00 & .25 & 1.00 & .40 \\
\hline L.S.D. at 5 \% for: Fungi (F) & $=0.05$ & & FX Fu & $=0.11$ & & \\
& Fungicide (Fu) & $=0.10$ & F X C & $=0.26$ & & \\
& Concentrations (c) & $=0.20$ & Fu XC & $=0.33$ & & \\
& & & F X Fu X C & $=0.53$ &
\end{tabular}

3.3.2. Effect of macroelements and microelements:

Data presented in Table (6) show that the macroelements were superior in decreasing F.solani $(3 \mathrm{~cm})$ linear growth compared with microelements, while, microelements were superior in decreasing F.oxysporum $(2.00 \mathrm{~cm})$ linear growth compared with macroelements. All concentration of macroelements and microelements significantly decreased linear growths of $F$. oxysporum, $R$. solani and $F$. solani than the control. Inhibition activity was significantly

increased by increasing concentrations of macroelements and microelements with all fungi tested.

3.3.3. Effect of ascobine and potasien:

All concentrations of Ascobine and Potasien (Table, 7) significantly decreased linear growth of F.oxysporum, R.solani and $F$. solani than the control. Inhibitory activity was significantly increased by increasing concentrations of Ascobine and Potasien with all fungi tested.

Table 6. Effect of microelement and macroelements on linear growth diameter $(\mathrm{cm})$ of three pathogenic fungi isolated from marigold.

\begin{tabular}{|c|c|c|c|c|c|c|c|c|}
\hline \multirow{2}{*}{$\begin{array}{l}\text { Concentrations } \\
\%\end{array}$} & \multicolumn{4}{|c|}{ Macroelements } & \multicolumn{4}{|c|}{ Microelements } \\
\hline & F.oxysporum & R.solani & F. solani & Mean & F.oxysporum & R.solani & F.solani & Mean \\
\hline 0.0 & 9.00 & 9.00 & 9.00 & 9.00 & 9.00 & 9.00 & 9.00 & 9.00 \\
\hline 3 & 6.20 & 6.00 & 5.75 & 5.9 & 6.00 & 5.55 & 6.00 & 6.00 \\
\hline 4 & 4.25 & 4.00 & 4.00 & 4.0 & 4.50 & 4.55 & 4.00 & 4.08 \\
\hline 5 & 3.25 & 2.25 & 1.50 & 2.6 & 2.00 & 2.55 & 2.15 & 2.00 \\
\hline \multicolumn{9}{|c|}{$\begin{aligned} \text { L.S.D. at 5\% for : } & \text { Fungi }(\mathrm{F}) \\
& \text { Treatments (T) } \\
& \text { Concentrations (c ) }\end{aligned}$} \\
\hline
\end{tabular}

Table 7. Effect of ascobein and Potasein on linear growth diameter $(\mathrm{cm})$ of three pathogenic fungi isolated from marigold.

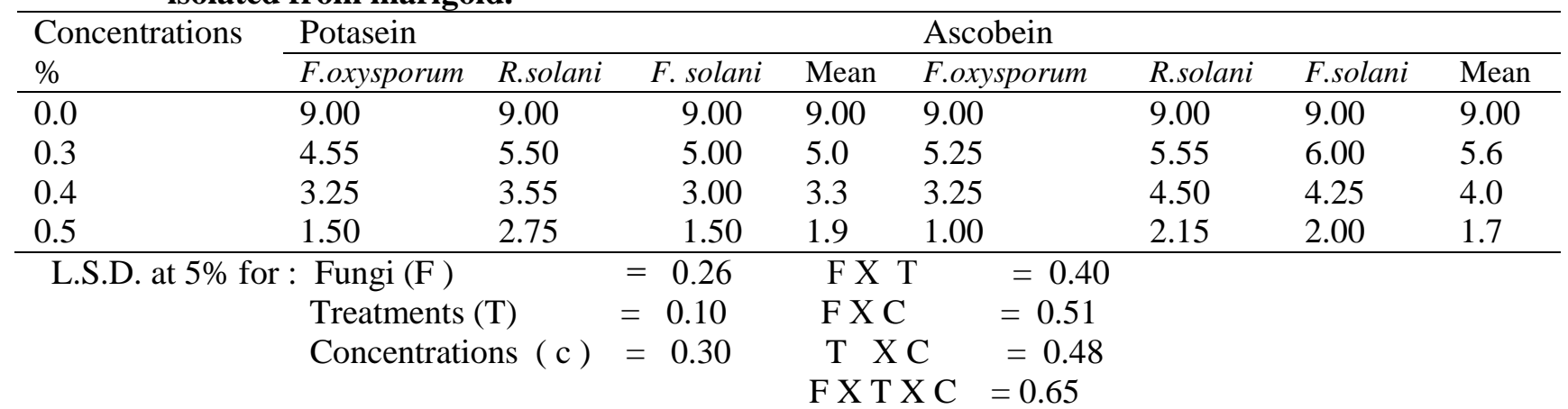


Scientific Journal of Agricultural Sciences 2 (1): 31-41, 2020

\subsubsection{Effect of Yeast ( Saccharomyces cerevisiae) on growth linear $(\mathrm{cm})$ of three pathogenic fungi isolated from marigold:}

All concentrations of yeast, (Table, 8 ) significantly decreased the linear growth of $F$. oxysporum, $R$. solani and $F$. solani than the control. Inhibitory activity was significantly increased by increasing concentrations of yeast used with all fungi tested.
3.3.5. Effect of garlic and onion on linear growth (cm) of three pathogenic fungi

\section{isolated from marigold.}

All concentrations of garlic and onion extracts ( Table, 9) significantly decreased the linear growth of $F$. oxysporum, R.solani and $F$. solani than the control. Inhibition activity was significantly increased by increasing concentrations of garlic and onion used with all tested fungi. Galic extract was significantly the most active than the onion extract against mycelial growth of three pathogenic fungi.

Table 8. Effect of yeast on linear growth diameter $(\mathrm{cm})$ of three pathogenic fungi of marigold.

\begin{tabular}{ccccc}
\hline (Concentrations grm) & F.oxysporum & R.solani & F.monliforme & Mean \\
\hline 0.0 & 9.00 & 9.00 & 9.00 & 9.00 \\
1 & 5.00 & 5.50 & 5.75 & 5.4 \\
2 & 4.00 & 5.00 & 3.25 & 4.0 \\
3 & 1.50 & 2.75 & 2.50 & 2.2 \\
\hline
\end{tabular}

L.S.D. at $5 \%$ for: Fungi $(\mathrm{F})=0.48$, Concentrations $(\mathrm{c})=0.34$, F X C $=1.00$

Table 9. Effect of garlic and onion extracts on linear growth of three pathogenic fungi isolated from marigold.

\begin{tabular}{ccccccccc}
\hline Concentrations $\%$ & \multicolumn{4}{c}{ Garlic extract } & \multicolumn{3}{c}{ Onion extract } \\
\hline & F.oxysporum & R.solani & F. solani & Mean & F.oxysporum & R.solani & F.solani & Mean \\
\hline 0.0 & 9.00 & 9.00 & 9.00 & 9.00 & 9.00 & 9.00 & 9.00 & 9.00 \\
25 & 2.0 & 4.0 & 4.0 & 3.3 & 4.25 & 4.0 & 5.00 & 3.6 \\
50 & 1.0 & 1.0 & 1.0 & 1.0 & 2.25 & 3.50 & 3.25 & 3.0 \\
\hline
\end{tabular}

L.S.D. at $5 \%$ for: Fungi $(\mathrm{F})=0.32$, Concentrations $(\mathrm{c})=0.40, \mathrm{~F} \mathrm{X} \mathrm{C}=0.77$.

\subsection{Field experiments:}

The effect of the treatments on the incidence of root rot and wilt of marigold plants under field conditions during 2017/2018 and 2018/2019 growing seasons is presented in Table (10) and (Figs. 1, 2, 3 and 4 ).

Data presented in Table (10) and ( Fig,1.2,3\&4) illustrate that all tested treatments significantly decreased the percentages of infection compared with control treatment. The lowest percentages of root rot and wilt $(6 \%)$ and $(8 \%)$ were resulted from treated transplants with Topsin M in 2017/2018 and 2018/2019 fungicide treatment proved to be the superior treatment, since it significantly decreased infection followed by garlic $(11 \%)$ and $(13 \%)$, respectively comparing with the other treatments. On the contrary, transplants treated with macroelements showed 31 and $33 \%$ infection by root rot and wilt diseases in 2017/2018 and 2018/2019 ,respectively. This was the least effective treatment followed by yeast.

On the other hand, all treatments significantly increased growth parameters compared with the control treatment. In this regarded Topsin $\mathrm{M}$ figured the highest growth parameters per plant with significant differences than the other treatments. However, measurements of growth parameters resulted from applying Topsin $\mathrm{M}$ were significantly more higher than those of the other treatments. As for dry weight /plant (g), all treatments recorded significant increases in dry weight /plant (gm) per plant as well as fresh flower yield compared with the control. Topsin $\mathrm{M}$ was, however, the best treatment in this respect.

\section{DISCUSSION}

Marigold is subjected to infection by several soilborne fungi, causing root rot and wilt diseases which represent a major problem in Egypt during the last decade. Important and destructive diseases, however, were previously recorded on marigold by (Sohi, 1983). Eight fungal isolates were isolated from naturally root rotted and wilted marigold plants. Fungal isolates were identified as Rhizoctonia solani, F. solani, F. oxysporum, $F$. roseum,Pythium splendens, $F$. subglutinans,. F.semitectum and F.nivale.

Pathogenicity tests demonstrated that F.oxyspoum ,F.solani and R.solani were pathogenic on marigold and showed typical symptoms of root rot and wilt. $R$. solani and $F$. oxysporum caused the highest pre- and post- emergence damping off, whereas F.nivale and F.roseum caused the lowest pre- and post- emergence damping off. These results agree with those obtained by (Sohi, 1983) .

A continuous monocropping system may result in negative impact on crop production, soil microbial diversity, and soil fertility (Monneveux et al., 2006; 
Gomma A. Abdel-Wahed., 2020

Table 10. Effect of various control measures on percentages of infection by root rot and wilt diseases also, fresh and dry weight /plant (g) of marigold plants grown under naturally infested field at 2017/18 and 2018/19 growing seasons .

\begin{tabular}{ccccccccc}
\hline & \multicolumn{3}{c}{$2017 / 2018$} & \multicolumn{3}{c}{$2018 / 2019$} \\
\cline { 2 - 8 } Treatments & $\begin{array}{c}\text { Infection } \\
\% \\
\text { (root rot } \\
\text { and wilt) }\end{array}$ & $\begin{array}{c}\text { Fresh } \\
\text { weight/ } \\
(\mathrm{g})\end{array}$ & $\begin{array}{c}\text { Dry } \\
\text { weight } \\
/(\mathrm{g})\end{array}$ & $\begin{array}{c}\text { Fresh } \\
\text { flower } \\
\text { weight per } \\
\text { plant/g }\end{array}$ & $\begin{array}{c}\text { Infection } \\
\% \\
\text { (root rot } \\
\text { and wilt) }\end{array}$ & $\begin{array}{c}\text { Fresh } \\
\text { weight / } \\
\text { (g) }\end{array}$ & $\begin{array}{c}\text { Dry } \\
\text { weight / } \\
\text { (g) }\end{array}$ & $\begin{array}{c}\text { Fresh } \\
\text { flower } \\
\text { weight } \\
\text { per plant } \\
\text { /g }\end{array}$ \\
\hline Topsin M & 6.0 & 2000 & 650 & 30 & 8.0 & 1950 & 650 & 29 \\
Vitavax 200 & 9.0 & 2100 & 700 & 25 & 10.0 & 2050 & 680 & 26 \\
Ascopine & 20.0 & 1500 & 500 & 20 & 19.0 & 1450 & 480 & 22 \\
Potasien & 25.5 & 1180 & 350 & 22 & 26.0 & 1150 & 385 & 20 \\
Micrelements & 17.0 & 988.3 & 320 & 24 & 20.0 & 960 & 320 & 25 \\
Macroelements & 31.0 & 915.8 & 305 & 15 & 33.0 & 900 & 300 & 16 \\
Yeast & 35.5 & 884.9 & 260 & 18 & 50.0 & 860 & 280 & 19 \\
Garlic extract & 11.0 & 1900 & 630 & 16 & 13.0 & 1850 & 600 & 15 \\
Onion_extract & 12.5 & 1950 & 650 & 13 & 15.0 & 1940 & 640 & 10 \\
Control & 65.0 & 600 & 200 & 9 & 66.0 & 590 & 190 & 8 \\
L.S.D.at 5\% : & 4.50 & 27.60 & 6.70 & 1.00 & 5.50 & 30.70 & 6.90 & 1.25 \\
\hline
\end{tabular}
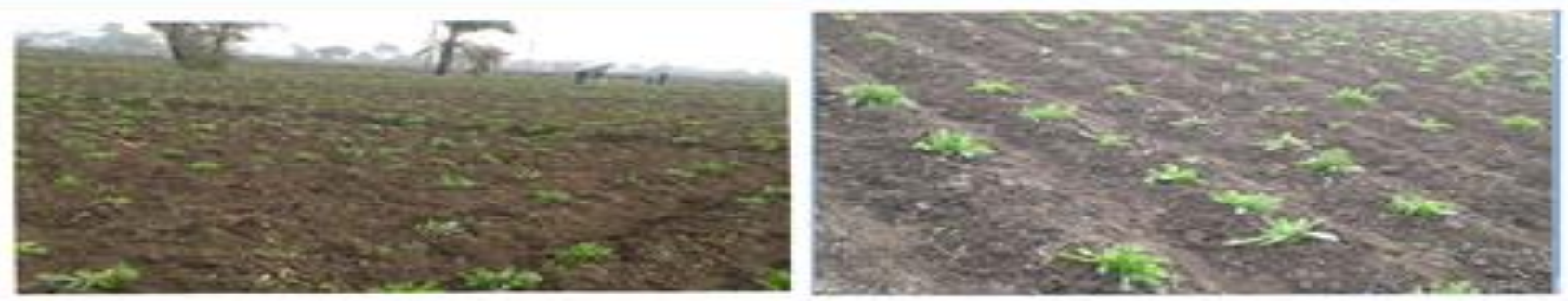

Fig. (1): Marigold plants showing pre-and post-energence damping-off.
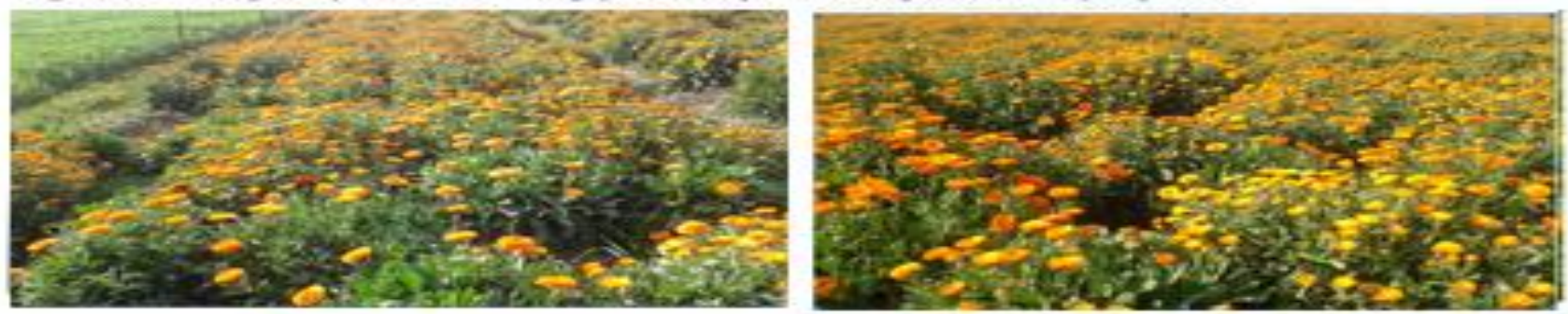

Fig- (2): Marigold plants treated with veast and Microclements.
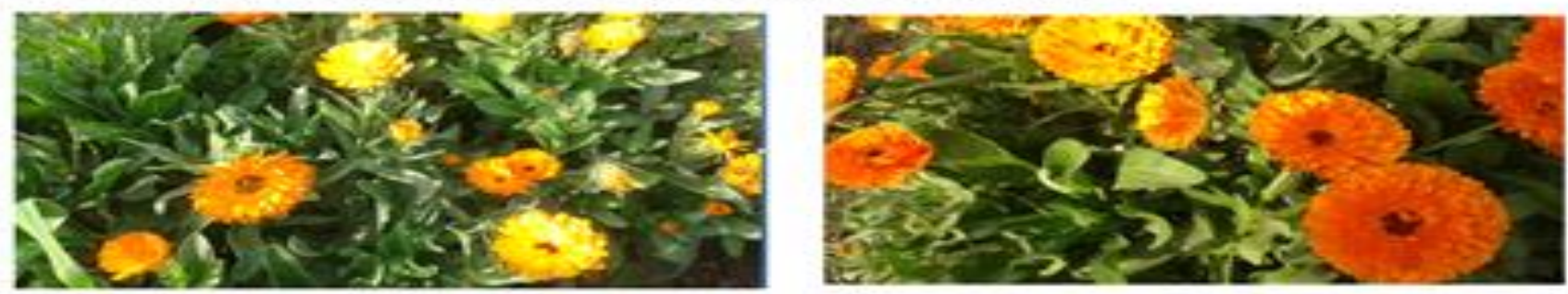

Fig. (3): Marigold plants treated with Vitavax 200 and Ascopine.
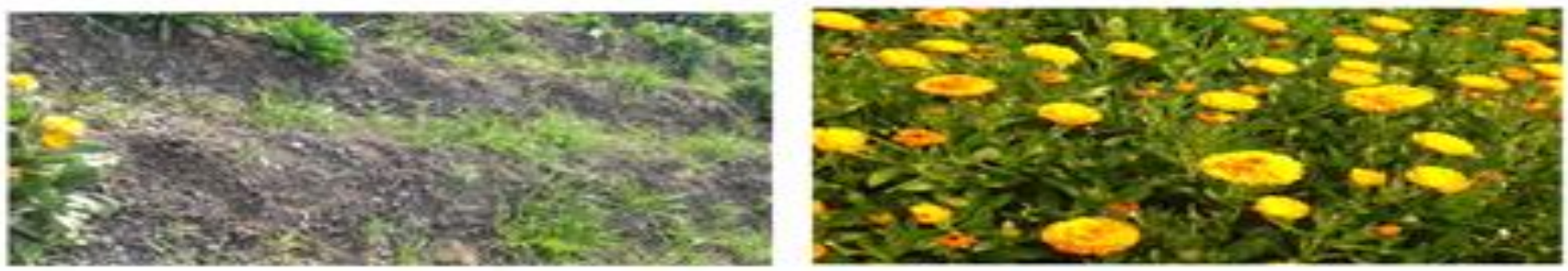

Fig. (4): Marigold plants untreated and treated with Topsin M. 


\section{Scientific Journal of Agricultural Sciences 2 (1): 31-41, 2020}

Ryszkowski et al., 1998; Wang and Chen,2005; Xu and Wang, 2003).

Results of the in vitro evaluation of Topsin $\mathrm{M}$, Vitavax 200, Ascopine, Potasien, micrelements, macroelements, yeast, garlic and onion extracts against the growth of root rot and wilt of marigold indicated that the tested concentrations of the tested treatments significantly reduced the linear growth of the tested pathogenic fungi .

Garlic contains more than 200 chemical compounds. Some of its more important ones include: volatile oil with sulphur-containing compounds: (allicin, alliin, and ajoene), and enzymes: (allinase, peroxidase and myrosinase). Allicin gives garlic its antibiotic properties and is responsible for its strong odor. Ajoene contributes to the anticoagulant action of garlic. The allyl contained in garlic is also found in several members of the onion family and is considered a very valuable therapeutic compound. Extracts of different concentrations of garlic were tested against the tested fungi in vitro. The obtained results proved significant effects of these materials causing a great reduction of the mycelial growth of the tested fungi. Garlic active compound may be produced as root exudates in soil planted with the concerned crops. Therefore, the obtained results may explain the reasons of the reduction in the diseases when marigold is grown after the garlic. The present results coincide with watermelon (Assadi and Behroozin 1987), onion white rot (Salama et al., 1988), Phaseolus aures collar rot (Lakshmanan and Mohan 1989), tomato wilt (Tariq and Magee, 2003 and Hilal et al., 2003). Yeast demonstrated the best control for marigold root- rot and wilt diseases, recording the lowest diseases. In the same time, this treatment gave the highest yield of herb fresh weight and oil percentage. The obtained results are in agreement with those obtained by Latte and Kolodziej (2000) and Buck (2004) on geranium seedlings. Ascobine and potassein proved to be the best control for marigold root- rot and wilt disease percentages, recording the lowest diseases. In the same time, these treatments gave the highest yield of herb fresh weight and oil percentage. The obtained results are in agreement with those obtained by Ahmed et al. (1998); Shaabauy, 2001 ; Mesbah et al. (2002); Mohamed et al. ( 2002), El-Din and Khalil (2003) and El-Sherbeny et al. (2007).

Macro and microelements proved to be the best control for marigold root- rot and wilt diseases. Percentages, of infection recorded the lowest diseases. In the same time, this treatment gave the highest yield of herb fresh weight. The obtained results are in agreement with those obtained in case of cowpea seedlings (Saharan and singh 1994), piper (Lakshmi et al., 1997), marjoram (El-Gebaly
1998), Lavendula multifida (Shoala 2000), geranium (Mohamed et al., 2002). Screening two fungicides (Topsin M-70\& Vitavax- 200) in vitro in PDA medium, against pathogenic fungi of marigold revealed that their inhibition varied according to :( 1) Kind of the fungal species, (2) Kind of the fungicide and (3) Concnetration of the fungicide. Topsin M-70 was significantly the superior fungicide than Vitavax -200 in controlling the tested fungi. On the other hand, inhibition of each fungicide was increased by increasing its concentration. In this respect, Horsfall (1956) mentioned that inhibition in mycelial growth may be due to the antifungal components act within the cell as inhibitors of vital process. Therefore, they must be able to penetrate cell membrane and gain access to the subcellular components, where, these processes occur. Moreover, the cellular membrane is belived to consist of lipoprotein of lipid solubility, such a necessary properity, therefore, to enable a compound to penetrate into the cell. However, Vitavax-200 and many other fungicides were reported as antifungal compounds of high soulibility. Moreover, Menten et al. (1976) reported that the fungicides may also differ in the ability of penetration and uptake via hyphae cell wall of the pathogens. Therefore, it may be stated that Vitavax 200 , which is primarily DMOC (5, 6-dihydro-2methyl -1,4-oxathiin -3-carboxanilide ) formulation, is more effective than Topsin M-70 probably because of the direct absorption of this compound without delay till further breakdown as for the other fungicide. Also, Vitavax (carboxin) might effectively inhibit the growth of fungi belonging to the Basidiomycetes including R.solani due to its interference with fungal respiration (Sijpesteijn, 1977).

On the other hand, efficacy of Topsin M-70 (thiophanate -methyl) may be resulted from the breakdown products of Methy - 2- benzimidazol carbamate; $\mathrm{MBC}$ and interference with mitosis, which proved to be the primary site of MBC action on such fungi. The superiority of Vitavax/Thiram for their inhibitory effect against R.solani growth was mentioned also by Kesavan (1984), Helmy-Alia, (1993), Khalifa (2003) Their results are in agreement with the present results.

The control means tested under naturally infested field soil conditions during 2017/2018 and 2018/2019 growing seasons. All diseases control trials significant minimizated of root rot and wilt diseases incidence and maximization of fresh weigh / plant than the controls during the two experimental seasons were recorded. Fungicides, however, was significantly superior than the others, followed by onion and garlic extracts. Also, significant increase 
Gomma A. Abdel-Wahed., 2020

in dry weight was recorded due to all using treatments.

\section{References}

Ahmed FF, Akl AM, Gobara AA, Mansour AE (1998). Yield and quality of Anna apple trees (Malus domestica L.) in response to foliar application of Ascobine and Citrine fertilizers.Egyptian- Journal-of-Horticulture. 25(2): 203-208.

Ahmed N, Sultan K (1984). Fungi toxic effect of garlic on treatment of jute seed .Bangladesh J. of Botany, 13 (2): 130 - 136 (c.f.Rev.Pl.Pathol., 65:1916, 1986).

Assadi P, Behroozin M (1987). The effect of bulb extracts of onion and garlic on the mycelial growth of Fusarium sp. and Sclerotium cepivorum. Iranian J. of P1. Pathol., 23(1-4):1-3, 1- 6 (Rev.Pl.Pathol., 67:6390, 1988).

Bernath J( 2000). Medicinal and Aromatic Plant. Mezo Publication, Budapest, p. 667,

Buck JW (2004). Combinations of fungicides with phylloplane yeasts for improved control of Botrytis cinerea on geranium seedlings. Phytopathology,94(2): 196-202.

Christensen CM (1957). Deterioration of stored grains by fungi. Bot. Rev., 23: 108- 134.

Dhingra OD, Sinclair JB (1995). Basic Plant Pathology. $2^{\text {nd }}$ ed., Lewis Publ., CRC Press, U S A, 434pp.

Dinda K, Craker LE (1998). Growers Guide to Medicinal Plants. HSMP Press. Amherst, P: 35-37,

Domsch KH, Gams W, Traute A (1980). Compendium of soil fungi. Academic Press .A subbidiary of Harcourt Brace Jovanvich Publishers, London, pp.859.

Dubey RC, Dwivedi RS (1991). Fungitoxic properties of some plant extracts against vegetative growth and sclerotial viability of Macrophomina phaseolina.Ind. Phytopathol., 44:411-413(c.f.Rev. Pl.Pathol., 71:6249, 1992).

El-Din AA, Khalil MY (2003). Effect of foliar fertilization on growth and yield of two Plantago species cultivated in Egypt.Egyptian- Journal-ofHorticulture. 2003; 30(3/4): 227-237.

El-Gebaly M M (1998). Studies on root - rot and wilt disease of marjoram. Ph D. Thesis, Fac. Agric., Al Azhar Univ

El-Sherbieny SE, Khalil MY, Hussein MS (2007). Growth and productivity of rue (Ruta graveolens) under different foliar fertilizers application. Journalof-Applied-Sciences-Research, : 399-407.

Gilman JB (1957). A Manual of soil fungi. Iowa State College Press, U.S.A. 450pp

Gomez KA, Gomez AA (1984). Statistical Procedures For Agricultural Research 2 ed, John Weley and Sons, Inc., New York.85(4):446.
Helmy Alia A, Baioumy MA, Hilal AA (1993). Frist record of root rot and wilt diseases of the medicinal plant Ruta graveolens L. in Egypt and their control .Egypt .J.Agric. Res., 79(1):21-35.

Hilal AA, Zaky WH, Nada MG (2003). New strategies for the management of some soilborne fungal diseases of the ornamental plants; croton and bulbous iris .Egypt. J. Appl.Sci., 18(12):64-90.

Horsfall JG (1956). Principles of Fungicidal Action. Waltham, Massachusetts, USA, 280 pp., 58.

Jens CF, Thanc V, Mathur SB ( 1991). An illustrated manual on identification some seedborne Aspergilli, Fusaria, Penicilia, and their Mycotoxins. Danish Government, Institute of Seed Pathologyfor Countries, Ryvans Alle 78, Dk, 2900 Hellerue, Denmark. (c.f. CABI Data base Abstracts).

Khalifa MM (2003). Pathological studies on charcoal rot disease of seasame. Ph. D. Thesis, Fac. Agric., Zag. Univ.

Kesavan $R$ (1984). In vitro efficacy of certain fungicides against Rhizoctonia solani and Sclerotium rolfsii. Fitopatologia Brasileira (Brasil), 9: 626- 630 (c.f.Rev. Pl. Pathol., 64: 231, 1985).

Lakshmanan P, Mohan S ( 1989). Antifungal properties of some plant extracts against collar rot of Phaseolus aureus .Madras.Agric J., 76 (5):266270(c.f. Rev.Pl. Pathol., 70:4580, 1991).

Lakshmi BC, Prasad MS, Balasubramani KA (1997). Influence of calcium nutrition on Fusarium decline of betelvine and activity of pectic enzymes. Ann. Agric. Res., 18 (2): 184 - 187. (C. F. Rev. Plant Pathol., 76 10:75).

Latte KP, Kolodziej H (2000). Antifungal effects of hydrolysable tannins and related compounds on dermatophytes, mould fungi and yeasts. Zeitschriftfur-Naturforschung-Section-C,-Biosciences. 55(5/6): 467-472.

Lestie JF, Summerell BA (2006). The Fusarium Laboratory Manual. Blackwell Publishing Ltd., Oxford, U.K.

Mardani-Nejad SH, Khold BB, Sadat Y, Morad AS, Vazir MP (2003)."Vegetative behavior change and the amount of essential oil of lavender (Lavandula officinalis) in response to different amounts of ammonium nitrate". Iranian Journal of Medicinal and Aromatic Plants, Vol. 19. P: 16-35.

Menten JO, Machado CC, Minussi E, Castro C, Castro $H$ (1976). Effect of some fungicides on mycelial growth of M.phaseolina (Tassi) Goid. in vitro. Fitopatologia Brasileira (Brasil), 1 (2): 57-66 (c.f.Rev. Pl. Pathol., 56 (8): 672-674).

Mesbah HA, Mourad AK, El-Nimr HM, El-Kady MB, Haroun NS (2002). Effect of sequential applications of foliar nutrients,biofertilizers and sowing dates on the incidence of corn stem borers in Egypt. Mededelingen-Faculteit-Landbouwkundige- 
en-Toegepaste- Biologische-Wetenschappen,Universiteit-Gent.2002; 67(3): 487-497.

Mohamed BR, khalifa SF, Mansour HA, Mohamed MA (2002). Effect of NPK Fertilization and micronutrients on vegetative growth and oil productivity of three geranium species. $2^{\text {nd }}$ inter. Sympos., orn. Hort. in orid zones. 1-3\4, AL-Ain united Arab Emirates.

Monneveux P, Quille_rou E, Sanchez C, LopezCesati J (2006). Effect of zero tillage and residues conservation on continuous maize cropping in a subtropical environment (Mexico). Plant Soil.279: 95-105.

Omed RB (2005). Production and Processing of Medicinal Plants. Vol. 2. Beh Nashr Press., P: 207,.

Plaats - Niterink AJ (1981). Monograph of the genus Pythium.Studies in Mycology, No 21, Centralburea Voor Schimmelcultures, Baarn,Netherland.

Riker AJ Riker RS (1936). Introduction to research on plant disease. Iohn, S. Swig, Co., St., New York, $117 \mathrm{pp}$.

Ryszkowski L, Szajdak L, Karg J (1998). Effects of continuous cropping of rye on soil biotic and biochemistry. Crit. Rev. Plant Sci.17: 225-244.

Saharan HS, Singh S (1994). Influence of soil amendements on the efficacy of fungicides against Rhizoctonia seedlings rot of Cowpea, Crop. Res. Hishar, 8(1): 159 - 161.

Salama AA, Ismail IM, Ali MI, Ouf SA (1988). Possible control of white rot disease of onion caused by Sclerotium cepivorum through soil amendment with Eucalyptus rostrata leaves. Revue d Ecologie et de Biologie du Sol., 25:305-314 (Rev. Plant Pathol., 68:6031, 1989).

Shalaby OY (1993). Studies on Fusarium wilt of muskmelon caused by Fusarium oxysporum f. sp. melonis in Fayoum. Ph. D. Thesis, Fac. Agric., Fayoum, Cairo Univ., Egypt.
Shaabauy MA (2001). Studies on some diseases that attack the root of cumin plant (Cuminum cyminum L.).Ph. D. Thesis, Fac. Agric.Moshtohor, Zagazig Univ., Benha Branch, Egypt.

Shoala AT (2000). Physiological Studies on Lavender Plant. Ph. D.Thesis, Fac. Agric., Cairo Univ.

Sijpesteijn AK (1977). Effects on fungal pathogens. In: Systemic fungicide (R.W. March), Longman, Inc., USA.

Singh VK, Singh Y, Kumar P (2012). Diseases of ornamental plants and their management, In: Ecofriendly innovative approaches in plant disease management. International Book Distributors and Publisher, New Delhi. pp. 543-572.

Sohi HS (1983). Personal Communication on diseases of marigold. I.I.H.R. Banglore.

Tariq, V. N. and Magee, A. C. 2003. Effects of volatiles from garlic bulb extracts on Fusarium oxysporum f. sp. lycopersici. Mycol. Res. 94:617620 Pawar, I. S. 1971.

Taya RS, Tripathi NN, Panwar MS (1988). Influence of soil type, soil moisture and fertilizers on the severity of chickpea root- rot caused by Rhizoctonia bataticola (Taub.) Butler. Ind. J. Mycol. and Pl.Pathol .18:2.

Topps JH, Wain RL (1957). Investigations on fungicides: III.The fungitoxicity of 3- and 5-alkylsalicylanilides and parachloroanilides. Ann.Appl.Biol. 45(3):506-511.

Wang MZ, Chen XN (2005). Obstacle and countermeasure of sustainable high yield for peanut in low-hilly red soil region. J. Peanut Sci. 34(2): 1722.

Xu RF, Wang XL (2003). Relation of microbial population dynamics and nutrient in soil of continuous cropping with peanut. J. Peanut Sci. 32(3): 19-24. 
Gomma A. Abdel-Wahed., 2020

الملخص العربـي

تطبيق بعض بدائل المبيدات لمقاومة أمراض أعفان الجذور والذبول الفطرية التي تصيب الأقحوان

جمعه عرفات عبد الواحد

قسم بحوث أمراض الزينة والنباتات الطبية والعطرية، معهد بحوث أمراض النبات، مركز البحوث الزراعية، الجيزة، مصر.

تنتشر أمراض أعفان الجذور والذبول على الأقحوان في مصر على نطاق واسع مما يتسبب في خسائر فادحة في الإنتاج .تم

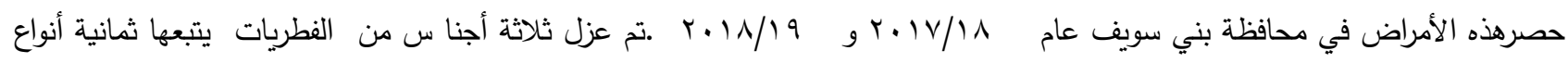

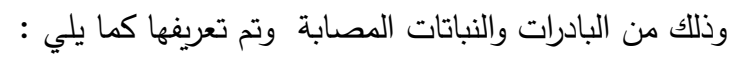

Fusarium.subglutinans, F.oxysporum, F.solani, F.semitectum, F.nivale, F.roseum, Rhizoctonia solani and

Pythium splendens.

أثتبت تجارب العزل للفطريات من العينات النباتية المصابة المجلوبة من محافظة بني سويف أن الفطر

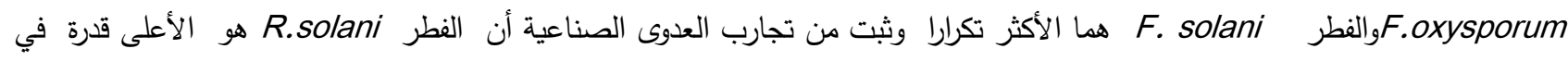
إحداث الإصابة وذلك تحت ظرورف الصوبة. وأثبتت تجارب تقييم تأثير المبيدات ومستخلص الثوم والبصل والاسكوبين والبوتاسين والعناصر

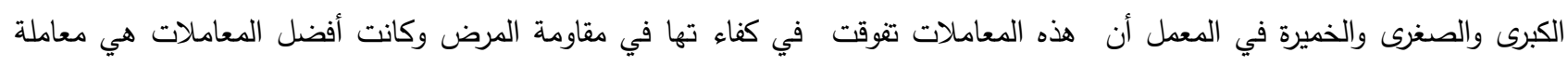

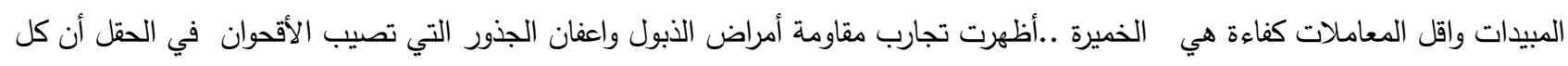

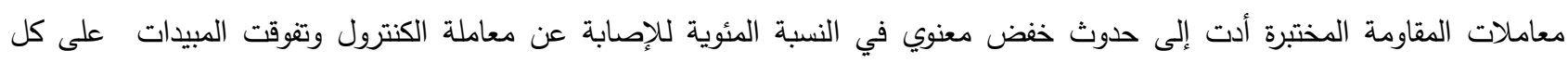

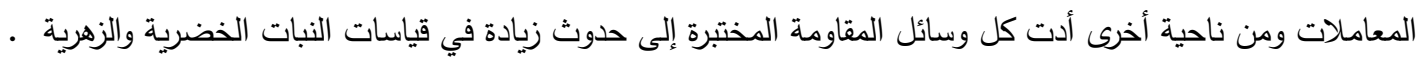

